\author{
Humberto R. Núñez Faraco \\ Department of Spanish, Portuguese \& Latin American Studies
}

UCL

h.faraco@ucl.ac.uk

\title{
The entanglements of freedom: Simón Bolívar's Jamaica Letter and its socio-political context (1810-1819)
}

By looking at the Jamaica Letter and other political writings of the period, this article explores some problematic aspects of Bolívar's thought regarding the capacity of Spanish Americans for self-government and the place assigned to marginalized ethnic groups within the revolutionary political process. Although it is nowadays revered as a great Americanist manifesto, Bolívar's Jamaica Letter was ultimately an attempt to reassure Britain of the commercial benefits that a military intervention in favour of Spanish American Independence would bring to her geopolitical ambitions. However, because of the reliance on slave workforce for its rich plantation economy, and in view of its pivotal commercial role in the Caribbean, Bolívar had also to guarantee the stability of British economic interests in the region. This also applied to New Granada (present-day Colombia) and Venezuela, where creole opposition to the abolition of slavery was strong. Thus, Bolívar avoided the issue of slavery and took a cautious approach with regard to the future status of Indian communities. In this respect, the Jamaica Letter reveals the inexistence of a unified national body during the Wars of Independence as well as the socio-political tensions entwined within such a fragmented and heterogeneous milieu.

Keywords: Civic virtue, freedom, political philosophy, republicanism, Simón Bolívar, Jamaica Letter 


\section{Introduction}

Simón Bolívar's Jamaica Letter is framed within a period of political revolt against Bourbon rule in Spanish America. Because of the radical administrative reforms introduced by the Crown during the second half of the eighteenth century, high-rank civil, military and ecclesiastical posts had become available almost exclusively to Peninsular Spaniards. High taxation, together with restrictions on trade, agriculture, mining and industry, were also a source of anger among the inhabitants of the colonies. ${ }^{1}$ Yet, they did not initially call for a revolution that would bring about their political independence. On the contrary, large sectors of the population viewed the colonial authorities as guarantors of their property and status. In Peru, the Indian rebellion led by Tupac Amaru II had shown that these could not be taken for granted, and similar events in other parts of the continent and the Caribbean during the last decade of the eighteenth century-particularly the black slave revolt in the rich French colony of Saint Domingue, which caused great human and material devastation-convinced the creole elites that nothing would be more disastrous for their interests and security than the absence of the colonial order itself. This was perceived as the primary structure capable of containing the social and ethnic war that would otherwise erupt in the region. ${ }^{2}$

Indeed, referring to Francisco de Miranda's expeditionary force to liberate Venezuela in 1806, the young Bolívar, who was at that time in Paris, expressed his own fears with regard to the consequences that such an action could have on the colony: 'Toutes les nouvelles qu'on nous donne sur l'expédition de Miranda sont un peu tristes, car on prétend qu'il a le projet de soulever le pays, ce qui peut causer beaucoup de mal aux habitants de la Colonie' [The news we get about Miranda's expedition are rather distressing as they say that he plans to liberate the country, which will cause much harm to the inhabitants of the colony]. ${ }^{3}$ In effect, by appealing to a large sector of the Venezuelan population, Miranda inadvertently created the mistrust of the creole elite 
with regard to the social consequences of his 'egalitarian' principles. ${ }^{4}$ Spanish colonial society, particularly in Venezuela, was built on a strict hierarchical order where family lineage and racial purity alone determined the place of individuals in the social edifice. Miranda knew this from personal experience, ${ }^{5}$ still, he relied on the assumption that popular support for his cause would be secured in the colonies through ideological persuasion, an expectation that proved to be completely erroneous. ${ }^{6}$

It was an external circumstance which triggered the chain of events that would compel Bolívar and other Spanish American Patriots to take the reins of their own political and economic affairs. The Napoleonic invasion of Spain in February 1808 and the subsequent abdication first of Charles IV and then of his son, Ferdinand VII, raised an outcry of popular indignation against the French throughout the Iberian Peninsula. In order to protect their national sovereignty the Spaniards formed local councils (juntas), which led to the creation of the representative national Cortes. ${ }^{7}$ As a logical reaction to the political turmoil in the Peninsula, Spanish Americans soon felt the need to establish autonomous provincial juntas to protect their own interests throughout the colonial territories. These juntas showed varying degrees of allegiance to the Spanish authorities, Lima and Mexico remaining under strong Royalist influence. In January 1809, moreover, the Spanish Central Junta decreed that the Spanish dominions in the Indies were no longer to be considered colonies but an integral part of the monarchy. ${ }^{8}$ Most creoles, however, distrusted the Central Junta's good intentions or the supposed legal equality it claimed to have established between americanos and peninsulares. ${ }^{9}$ Thus, after two failed attempts to create an autonomous local junta, in April 1810 the Province of Caracas (Captaincy-General of Venezuela) succeeded in overthrowing the Spanish authorities. In an ingenious statement, the Caracas Junta maintained its formal obedience to the monarch but refused to accept the legitimacy of the Regency, the 
Spanish national governing body that was set up in January 1810 to fill the gap left by the abdication of Ferdinand VII. ${ }^{10}$

Not all the Venezuelan provinces followed the example of Caracas. This situation was to weaken the effectiveness of the first Constituent Congress of the Venezuelan Provinces, which declared absolute Independence from Spain in July 1811 and the creation of a federal republic, namely, the United States of Venezuela. In the end, the lack of political agreement towards a common goal and the subsequent fragmentation of the Confederation sealed its fate: civil war became inevitable and by July 1812, after a devastating earthquake that destroyed Caracas, the dream of a harmonious, prosperous and free Venezuela had completely vanished. Francisco de Miranda, who had returned from London less than two years earlier and was now fighting the Royalist forces as commander in chief of the Venezuelan Confederation, was thus forced to accept the terms of a capitulation recognising the Cortes and the reinstatement of Spanish rule. ${ }^{11}$

As a privileged and enlightened young man with strong commercial interests in mining and agriculture, Bolívar was eager to play a leading role in the emancipation of his homeland and the creation of a prosperous liberal order that would guarantee the rights, property and security of its people. In June 1810, the newly created Junta dispatched him on an official mission to London together with Luis López Méndez and Andrés Bello. Bolívar, who took upon himself the financial costs of the journey, was to seek British protection from the menace of a French invasion of Venezuela and to reassure the British government that the Caracas Junta remained faithful to the Spanish Crown. Bolívar, nevertheless, disregarded the Junta's directives and requested instead British recognition of the Venezuelan Independence. Richard Wellesley_-brother of Lord Wellington—refused Bolívar's request. Despite his poor opinion of the Spanish 
government, Wellesley, who was then Foreign Secretary, remained adamant in his view that a full recognition of the Regency was the appropriate course of action. Now that Britain and Spain were allied against a common enemy, there was no chance of obtaining British support in a political revolt against colonial rule in Spanish America. ${ }^{12}$ International politics aside, the incident is interesting in that it shows Bolívar's radical stance with regard to the question of independence: he wanted an absolute break with Spain (with or without the support of Britain) and would not agree to compromise.

Despite his failure to obtain British backing for Independence, Bolívar's discussions in London secured the protection of Caracas against a possible French invasion and, thanks to British 'neutrality', opened up a channel of communication that would enable the rebel forces in Venezuela to obtain indirect military and financial aid in the years to come (for this purpose, López Méndez was allowed to remain in London with the task of recruiting British mercenaries to fight in South America). ${ }^{13}$ At a personal level, his stay in London gave him the opportunity to meet a number of Spanish American Patriots living in exile, among them Francisco de Miranda, who introduced Bolívar to prominent British political and intellectual figures. Since the 1790s, Miranda had spent all his energies trying to convince the British Government to support his plans for the emancipation of the Spanish colonies, but the volatile nature of Anglo-Spanish diplomacy had made this impossible. Miranda, however, was not entirely trusted by the British nor by the Venezuelan elite in Caracas. In particular, his military involvement in the French Revolution during the years 1792-1793 meant that he was seen as a threat to the political stability of the colonies with their strong grasp on social privileges and economic interests. ${ }^{14}$ From this perspective, the example of the French Revolution was considered a deterrent rather than an encouragement for rebellion in South America. After all, had not the ideas about liberty and equality 
unleashed the fall of Saint Domingue? Miranda, who actually shared this assessment of the Revolution (not least because of the persecution he suffered in France under the Girondists), was nevertheless able to make a good impression on Bolívar. ${ }^{15}$ In fact, it might not be entirely far-fetched to think that he could have influenced Bolívar's hard stance in the discussions with Wellesley. At any rate, Miranda finally abandoned the hope of leading a British-backed military expedition to liberate the colonies and decided instead to join the revolutionaries in Caracas. His military and diplomatic experience, combined with his intellectual background, accredited, in his view, a well-deserved place in the political life of his patria.

Soon after the conversations with Wellesley were over, Bolívar returned to Venezuela where he joined, together with Miranda, the military struggle for the liberation of his country. Tragically, with the capitulation of July 1812 and the disbandment of the army, Bolívar felt that Miranda had betrayed the cause for independence. ${ }^{16} \mathrm{He}$ was therefore instrumental in the latter's capture by the Royalists, who kept him imprisoned until his death in Cadiz four years later.

\section{The Cartagena Manifesto}

After the Capitulation of San Mateo Bolívar sought refuge in Cartagena, the main colonial port in New Granada (present-day Colombia) and now the administrative centre of a nominally independent republic. It was there that he delivered his first important speech on political theory, the Cartagena Manifesto, a reflection on the Venezuelan first republican experiment and its failures. The document outlines Bolívar's political creed, not only with regard to the principles of government he believed were appropriate for a free Venezuelan republic but also with respect to the affirmation of power and authority over, as he put it, the 'ignorant people' who are 
incapable by themselves of reinforcing their legitimate rights ('los pueblos estúpidos que desconocen el valor de sus derechos'). ${ }^{17}$ In the Manifesto, he openly criticises the lack of vigour exerted by the Caracas junta in subduing the dissident provinces and mocks the 'idealist' axioms of its members, who confused philosophical speculation with practical government:

Los códigos que consultaban nuestros magistrados no eran los que podían enseñarles la ciencia práctica del Gobierno, sino los que han formado ciertos buenos visionarios que, imaginándose repúblicas aéreas, han procurado alcanzar la perfección política, presuponiendo la perfectibilidad del linaje humano.

[The operating codes our leaders consulted weren't those they might have learned from any practical science of governance, but those formulated by certain worthy visionaries who, conceiving some ethereal republics, sought to achieve political perfection on the presumption of the perfectibility of the human species. ${ }^{18}$

Bolívar's pragmatism and his conviction that a politico-administrative agreement throughout the Venezuelan territory was necessary for the conservation of Independence explains his insistence on the need for a robust and centralised form of government. He never changed his mind on this point. The Venezuelan Constitution of 1811 had been drafted along the lines of the North American federal constitution. ${ }^{19}$ Bolívar, who had been opposed to the adoption of a federal system because of the separatist tendencies of the provinces and their capacity to act against the interests of the nation ('exaltando el espíritu de provincia que forzosamente debilita y entorpece el de nación'), ${ }^{20}$ could now blame the lack of a solid, centralised power for the evils suffered during the First Republic: 
Pero lo que debilitó más el Gobierno de Venezuela fue la forma federal que adoptó, siguiendo las máximas exageradas de los derechos del hombre, que autorizándolo para que se rija por sí mismo, rompe los pactos sociales y constituye a las naciones en anarquía. [...] Generalmente hablando, todavía nuestros conciudadanos no se hallan en aptitud de ejercer por sí mismos y ampliamente sus derechos; porque carecen de las virtudes políticas que caracterizan al verdadero republicano; virtudes que no se adquieren en los gobiernos absolutos, en donde se desconocen los derechos y los deberes del ciudadano.

[But what most weakened the government of Venezuela was the federal structure it adopted, embodying the exaggerated notion of the rights of man. By stipulating that each man should rule himself, this idea undermines social compacts and constitutes nations in a state of anarchy. [...] Generally speaking, our fellow citizens are not yet ready to take on the full and independent exercise of their rights, because they lack the political virtues marking the true citizen of a republic. Such virtues are impossible to attain in absolutist governments, where there is no training in the rights or duties of citizenship.] ${ }^{21}$

Indeed, as opposed to English colonial rule in North America — where civil rights and liberties had been enjoyed—Spanish Americans had not been able to develop a collective sense of duty and responsibility on which to base a common political goal. ${ }^{22}$ These notions were ineffective because Spanish colonial society had been built upon the premise of social and racial difference, a situation that resulted in the marginalisation of large sectors of the population and their consequent inability to represent themselves as being part of a political community that went beyond narrow regional or ethnic interests. ${ }^{23}$ Given the complexities of such a fragmented, ill-prepared society, it was clear that in the short term neither federalism nor a universal electoral system would be suitable for the people of Venezuela:

Las elecciones populares hechas por los rústicos del campo y por los intrigantes moradores de las ciudades, añaden un obstáculo más a la práctica de la federación entre nosotros, porque los unos son tan ignorantes que hacen sus votaciones maquinalmente, y los otros tan ambiciosos que todo lo convierten en facción; por lo que jamás se vio en Venezuela 
una votación libre y acertada, lo que ponía el gobierno en manos de hombres ya desafectos a la causa, ya ineptos, ya inmorales.

[The popular elections conducted by the rustic inhabitants of the countryside and by the intriguers living in the cities pose an additional obstacle to the practice of federation among us, because the former are so ignorant that they vote mechanically while the latter are so ambitious that they turn everything into factions. Therefore, we never experienced a free, correct election in Venezuela, so that the government ended up in the hands of men who were incompetent, corrupt, or uncommitted to the cause of independence. $]^{24}$

Bolívar's complaint about the inexistence of a republican political ethos in Spanish America will have fundamental repercussions in his constitutional projects. In his view, the greatest challenge posed by the Spanish American Wars of Independence came from within. While war could eventually bring peace (through a military solution to the conflict), only the rational acceptance of a new constitutional order on the part of each individual citizen would be able to create the conditions under which a free and stable republic could prosper for the benefit of all. As he stated in 1818:

Sois todos venezolanos, hijos de una misma Patria, miembros de una misma sociedad, y ciudadanos de una misma República. El clamor de Venezuela es libertad y paz: nuestras armas conquistarán la paz, y vuestra sabiduría nos dará la libertad.

[You are all Venezuelans, natives of the same country, members of the same society, and citizens of the same Republic. The clamour of Venezuela is liberty and peace; our arms shall conquer peace, and your wisdom will give us liberty. $]^{25}$

This implied the consolidation of a political community where citizens would respect each other on account of their shared rights and responsibilities before the law. In order to contribute positively to society Spanish Americans needed to act unselfishly and for the benefit of the common good. This was essential both for the protection of the region 
against the threat of a Spanish reconquest and to stop the spread of a fratricidal war between cities and provinces. Yet, the prevailing state of corruption and opportunism in the political and administrative sphere represented a serious obstacle in the struggle for independence and paved the way for social and political anarchy. ${ }^{26}$ If Spanish colonial rule had curtailed the growth of liberal institutions, the Wars of Independence had brought a vicious and harmful sense of political freedom. Amid so many conflicting interests, Bolívar felt that only a centralised and authoritarian government could save the republican project from self-destruction.

\section{Jamaica and the political impasse}

When Bolívar wrote the Jamaica Letter he had behind him a trail of glory and defeat. Through the military campaign initiated in 1813 he was able to liberate Caracas from Spanish rule. Yet, the persistence of old factions determined once again the failure of his achievements. By September 1814 Bolívar was back in New Granada. This, too, was the scene of politico-administrative divisions. Following his military success in Santa Fe (the former capital of the viceroyalty), Bolívar marched north where he encountered rebellious opposition from Cartagena. As he laid siege to the Caribbean city in March 1815, the Royalist forces that still dominated the northern province of Santa Marta were able to expand their control over the area. In order to avoid greater evils, Bolívar abandoned the command of the New Granadan troops and sailed for Jamaica hoping to find in the British colony an alternative path for the solution of the Venezuelan predicament. $^{27}$

During his eight-month exile in Jamaica, Bolívar sought financial, military and logistic support from Britain: 'The balance of world power and the interests of Great Britain are perfectly in accord with the salvation of America!'- - he states in a letter to 
Richard Wellesley, desperately asking for British succour in the struggle for Independence- - 'England [...] will see prosperity flow back to her shores from this hemisphere which must depend, almost exclusively, on her as benefactress. ${ }^{28}$ The cause of Bolívar's despair was the return of Ferdinand VII to the throne (back in March 1814) and his determination to subdue at any cost the rebel colonies in Spanish America. With that purpose, Pablo Morillo, an experienced army officer in command of a large military force, reached the coast of Venezuela in March 1815. By the time Bolívar was writing the Jamaica Letter in September of that year, Caracas had already fallen to Morillo's army; Cartagena would fall early in December, followed by Santa Fe in May $1816 .{ }^{29}$

The Jamaica Letter, then, is essentially a moral and political justification of the Wars of Independence and a call for international support in the struggle for the emancipation of the Spanish colonies. Although it is nowadays revered as a great Americanist manifesto, Bolívar's targeted audience was certainly not to be found among the native population in Spanish America. ${ }^{30}$ As his letters to Wellesley and others show, Bolívar's ultimate plan was to reassure the British government of the commercial benefits that a military intervention in favour of the rebel cause would bring to its geopolitical interests. Writing to Maxwell Hyslop, a prominent English merchant based in Jamaica, Bolívar goes as far as to suggest the possibility of handing over Panama and Nicaragua to Britain — an idea that would have outraged Miranda, who always distrusted its imperialist ambitions. ${ }^{31}$

From a polemical point of view, the Jamaica Letter presents a grim vision of the Conquest and colonisation of the New World, the predicament of its inhabitants under Bourbon rule, and the possible political organisation of the colonies once the ties with Spain had been severed and a liberal and prosperous economic order was established in the Spanish American territories. ${ }^{32}$ Although in his appeal for international support 
Bolívar underscores the legitimacy of the rebel cause, his outlook regarding the political aptitude of the Spanish American people for self-rule_-indeed, their willingness to develop adequate republican institutions - is nevertheless extremely pessimistic, as the following statement reveals:

¿Seremos nosotros capaces de mantener en su verdadero equilibrio la difícil carga de una república? ¿Se puede concebir que un pueblo recientemente desencadenado se lance a la esfera de la libertad sin que, como a Ícaro, se le deshagan las alas y recaiga en el abismo? Tal prodigio es inconcebible, nunca visto. Por consiguiente, no hay un raciocinio verosímil que nos halague con esta esperanza.

[Shall we be able to maintain, in its true equilibrium, the difficult charge of a republic? Is it to be conceived, that a people but just released from their chains can fly at once into the sphere of liberty? Like Icarus, their wings would be loosened, and they would refall into the abyss. Such a prodigy is inconceivable, in fact never seen; consequently, there is no reasonable argument which can bear us out in this expectation. $]^{33}$

It was paradoxical that the very people who had demanded their Independence just a few years earlier should now prove unfit for the challenges that lie ahead. If Bolívar was seeking the support of Britain — as indeed he was—it is puzzling that he should raise such a devastating caveat against the project of emancipation. There is a distant echo here of eighteenth-century perceptions of the inhabitants of the New World (such as the pseudo-scientific theories of Buffon, De Pauw and the like), in which Spanish American peoples were stigmatised as inferior or barbaric races incapable of progress and self-government. ${ }^{34}$ In the eyes of European and North American observers, this negative appraisal constituted a serious indictment against creoles for it questioned their capacity to create civilized and industrious societies - no previous experience of political liberty and self-rule could attest to the contrary- This meant a fundamental flaw in the political development of Spanish Americans, a weakness that manifested 
itself through their unruliness, arbitrariness and personal ambition, an issue frequently mentioned by Bolívar in his private correspondence. ${ }^{35}$ Yet, as far as the Jamaica Letter is concerned, Bolívar's accusation against his compatriots explains his anxious (and rather problematic) desire for Britain to take her place as benefactress of the future republics: 'Luego que seamos fuertes, bajo los auspicios de una nación liberal que nos preste su protección, se nos verá de acuerdo cultivar las virtudes y los talentos que conducen a la gloria' [As soon as we become strong, and under the auspices of a liberal nation that will afford us protection, we shall be united fin cultivating the virtues and talents that lead to glory $\}] .{ }^{36}$ In other words, the political immaturity of Spanish Americans at that historical junction justified in Bolívar's eyes the need for a foreign power to oversee the development of the young republics for as long as the circumstances should require it, thus creating the perfect conditions for a new kind of colonial dependency.

Could obstacles of such a magnitude be overcome through the implementation of liberal institutions alone? While civil liberty depended on the solidity of the political institutions to be adopted, the latter had to be based on the actual preparedness of Spanish Americans for freedom. In this respect, Bolívar's distrust of his own people shares similarities with Thomas Jefferson's assessment of the Spanish American predicament and prefigures G. W. F. Hegel's criticism of the new republics: 'I feared from the beginning that these people were not yet sufficiently enlightened for selfgovernment; and that after wading through blood and slaughter, they would end in military tyrannies, more or less numerous. ${ }^{37}$ This situation created a vicious circle for which Bolívar had yet to find a political remedy. However, despite the reproach of his adversaries (and the condemnatory verdict of later generations), he always resisted the idea of military dictatorship as a cure for the malady. ${ }^{38}$ As he stated in his address to the 
Angostura Congress, his project was fixed in the conviction that a truly republican order in South America required the consolidation of civil and political liberties based on a new kind of education for its citizens; this implied the creation of a new society built on civic virtue and moral responsibility. ${ }^{39}$ This was Bolívar's aim, even if in the short term the concrete socio-political circumstances required a degree of 'enlightened' authoritarianism in order to keep the republic safe: 'If, during the last years of our disastrous struggle a plenitude of power has been invested with me, now that we have a prospect of tranquillity, however distant, I wish to show that it has been the consequence of necessity and of circumstances and not of intrigues or any pretensions on my part. ${ }^{40}$ It is against the backdrop of civil war, administrative corruption and a widespread absence of republican values, therefore, that his ideas on governance and autocracy need to be seen. In my opinion, the latter was an attempt to overcome those obstacles rather than an end in itself. ${ }^{41}$

\section{The social dimension}

Because of the reliance on slave workforce for her rich sugar and cacao plantations, and in view of her pivotal commercial role in the Caribbean, Bolívar had to recognize that the guarantee of social order and security was paramount to British economic interests in Jamaica. This also applied to certain regions in New Granada and Venezuela where creole opposition to the abolition of slavery was essential for the survival of their plantation economy. ${ }^{42}$ With regard to the question of black slavery, then, Bolívar had to find a middle term that would reconcile the various political and economic interests that were at stake in the region. His sojourn in Haiti between 15 December 1815 and 16 April 1816, where he received a generous military support from President Alexandre Pétion, forced him to consider the problem under a new light. ${ }^{43}$ More than any 
considerations of humanity and justice, the promise of freedom in exchange for the slaves' enlisting in the Patriot militias was now a matter of sheer necessity. ${ }^{44}$ Bolívarlike Antonio Nariño in New Granada in 1813 - had to come to terms with the fact that without the recruitment of slaves and free people of colour in general, a military success over the Royalist army was uncertain. The Royalist forces themselves had been successful in recruiting black slaves for their troops, some of which had fought bravely against the Patriot armies. Since slave and mulatto opposition to the republican cause had played a significant role in the fall of the first and second republic, it was now essential to gain their support in order to avoid further damage. ${ }^{45}$ To be sure, the fortune of the republican project depended on this; yet, Bolívar twisted the argument by making conscription a precondition of freedom as much as a moral duty on the part of the slaves themselves. As he put it: 'No habrá, pues, más esclavos en Venezuela que los que quieran serlo' [There will no longer be any slaves in Venezuela except those who wish to remain so]. ${ }^{46}$ In the quest for the independence of Venezuela and New Granada after 1816, Bolívar's position vis-à-vis the issue of slave emancipation would continue to be entirely pragmatic and, at times, somewhat cynical. Writing to Santander a few years later, he says: 'Cada vez me confirmo más en la utilidad de sacar esclavos para el servicio; el primero que los llama es su libertador' [I am day by day more convinced about the usefulness of recruiting slaves for the army; the first one to call upon them is their Liberator]. ${ }^{47}$ As far as the slaves was concerned, however, his offer must have meant little more than a certain death in the battlefield. Bolívar himself confirms this suspicion; in a letter to Santander written a month earlier, he argues: ¿¿Será justo que mueran solamente los hombres libres por emancipar a los esclavos? ¿No será útil que estos adquieran sus derechos en el campo de batalla, y que se disminuya su peligroso número por un medio poderoso y legítimo?' [Can it be just that only free men should 
die for the emancipation of the slaves? Would it not be better that the latter win their rights on the field of battle and that their dangerous numbers be reduced through a powerful and legitimate action?]. ${ }^{48}$ On the other hand, late colonial experience in some regions of Venezuela and New Granada shows that life as a fugitive could offer slaves and other subaltern groups a better option for survival and self-affirmation, one which did not exclude the prospect of organising their own rebellions against white rule. ${ }^{49}$

Just as Bolívar avoided the issue of slavery in the Jamaica Letter he also took a cautious approach with regard to the status of Indian communities in the future independent countries (the terms 'slavery' and 'enslavement' appear only as a metaphorical description of the oppression suffered by the creoles under colonial rule, a rhetorical device that had become commonplace in Patriot discourse since 1810). ${ }^{50}$ Given that this was not an indigenous or peasant uprising in the style of the Andean rebellions of the $1780 \mathrm{~s}$, the administrative vacuum created by the separation of the colonies from Spain could theoretically put into question the legitimacy of the creole class to take over the political control of indigenous peoples in various parts of the continent. Indeed, in a manuscript to the editor of the Royal Gazette written during his stay in Jamaica, Bolívar was all too keen to emphasize the 'natural' subordination of Indians and blacks with respect to the 'superior' moral and intellectual capacity of their white masters. ${ }^{51}$ Bolívar's aim in writing this document was twofold: firstly, to reassure Britain that the conditions for Independence and economic prosperity in the Spanish colonies were secured under creole leadership; secondly, to indicate that the 'amicable' relationship between creoles and the castes guaranteed the peace and security of the new republics. After all—he argues in the Jamaica Letter — had not the Spanish Conquistadors been rewarded by the king with land and other royal privileges for their exclusive enjoyment and those of their descendants, so that 'they should take the 
"indigenes" under their protection as vassals" ${ }^{52}$ By the same token, the South American Wars of Independence were fought for the promotion and defence of creole interests, even if the ranks of the troops included a wide sector of the population each with their own set of grievances and aspirations. ${ }^{53}$ Yet, the traditional characterization of Indians as belonging to a primitive or inferior race that had been left outside the course of history after the Spanish Conquest, was largely used as a justification for their marginalisation from the core structure of civil society. ${ }^{54}$ This implied an affirmation of the creoles' colonial heritage at the expense of Indian rights, including the claims of indigenous communities to land and self-determination. ${ }^{55}$ Bolívar states it bluntly:

Yo considero el estado actual de la América, como cuando desplomado el Imperio Romano cada desmembración formó un sistema político, conforme a sus intereses y situación o siguiendo la ambición particular de algunos jefes, familias, o corporaciones; con esta notable diferencia, que aquellos miembros dispersos volvían a restablecer sus antiguas naciones con las alteraciones que exigían las cosas o los sucesos; mas nosotros, que apenas conservamos vestigios de lo que en otro tiempo fue, y que por otra parte no somos indios ni europeos, sino una especie media entre los legítimos propietarios del país y los usurpadores españoles: en suma, siendo nosotros americanos por nacimiento y nuestros derechos los de Europa, tenemos que disputar éstos a los del país y que mantenernos en él contra la invasión de los invasores.

[I consider the present state of America as similar to that of imperial Rome, when she was decaying: Every division formed for itself a political system, agreeable to its interests and situation, or followed the particular ambition of certain chiefs, families, or corporations; with this remarkable difference, that the dispersed tribes re-established their ancient customs, with such alterations as were required by circumstances. But we, hardly preserving a vestige of our former state, neither Indians nor Europeans, but a race between the original natives and the European Spaniards; being by birth Americans, and our rights those of Europe, we have to dispute and fight for these contending interests, and to persevere in our endeavours notwithstanding the opposition of our invaders. $]^{56}$ 
Bolívar's comparison between the fall of the Roman Empire and the dissolution of the Spanish colonial order allows him to formulate a crucial political argument: while the disintegration of the former empire led to the restoration of autonomous political communities in the Italian Peninsula (and elsewhere), the separation of the colonies from the Spanish Crown revealed the absence of a unified national body capable of reconstituting a historical form of political organisation based on freedom and selfrule. ${ }^{57}$ Such a condition could no longer be claimed by the descendants of the preColumbian peoples (whose political institutions had been practically destroyed) nor by the creoles (whose status as colonial subjects had impeded a genuine experience of political freedom). While some commentators of Bolívar's social thought have interpreted the original Spanish expression 'una especie media' as a reference to the future development of a mestizo society in Spanish America that will reconcile its ethnic differences (an idea he will present in his address to the Angostura Congress, although not in particularly strong or unambiguous terms $),{ }^{58}$ there is no direct connection in the Jamaica Letter between his call for Independence and the consolidation of a homogeneous national body after the emancipation of the colonies. Within the political context of the document, the phrase 'una especie media' implies a juridical rather than a socio-biological perspective (the use of the term 'race' in the English translation of the Letter published in Jamaica can therefore be misleading). At no point does Bolívar suggest here the existence of a large mestizo population that would take over the prerogatives of the creole class. While he did not publicly promote discriminatory social policies, the creation of a harmonious political community formed by free and equal americanos was at this stage totally unattainable. Social reality in Spanish America was altogether of a different kind: it was determined by a multiplicity of regional and ethnic identities struggling against each other for their own political and economic interests. ${ }^{59}$ 
In this respect, the Jamaica Letter reveals the lack of a unified national body during the Wars of Independence as well as the socio-political tensions entwined within such a fragmented and heterogeneous milieu.

\section{Conclusion}

In his project for a free and united continent, Bolívar expressed in 1815 the need for a confederation of Spanish American states linked together by a common political goal:

Es una idea grandiosa pretender formar de todo el Mundo Nuevo una sola nación con un solo vínculo que ligue sus partes entre sí y con el todo. [...] Mas no es posible, porque climas remotos, situaciones diversas, intereses opuestos, caracteres desemejantes, dividen a la América. [...] Esta especie de corporación podrá tener lugar en alguna época dichosa de nuestra regeneración; otra esperanza es infundada.

[It is a most magnificent idea, that of forming the new world into one great nation, linked together by one great chain. [...] But it is impossible, for distant regions, various situations, contending interests, and dissimilar characters, divide America. [...] This sort of corporation may very possibly occur during some happy epoch of our regeneracy: Any other expectation is futile. $]^{60}$

This Bolivarian ideal has come down through generations of Americanist manifestos as a grandiose political scheme that would protect Spanish American countries from the threat of imperialist intrusions (Bolívar would nonetheless be keen on having the presence of British delegates at the Panama Congress of 1826). However, far from assuming the factuality of a Pan-American union, Bolívar knew that its concrete realisation in the former Spanish colonies required the consolidation of civil societies based on the exercise of political virtue. ${ }^{61}$ This was needed in order to strengthen a sense of trust and solidarity among its nations. Hence, the notion that the 
political 'regeneration' of the people is a prerequisite for their progress as civilized nations of the world suggests a rather cautious view with regard to the success of such a scheme, at least in the foreseeable future (I interpret the expression 'our regeneracy' in socio-political terms, that is, as the ideal point in history in which Spanish American societies will realize their capacity for freedom as rational political communities). In the short run, nevertheless, the difficulty of creating stable political institutions capable of guaranteeing unity, prosperity and mutual cooperation-whether regional, national or Pan-American - constituted a palpable threat to the ideals of the revolution. In order to achieve a true and lasting Independence, social and political integration, coupled with a solid education in civic norms and values, was urgently needed. As Bolívar put it: 'Si hay alguna violencia justa, es aquella que se emplea en hacer a los hombres buenos y, por consiguiente, felices; y no hay libertad legítima sino cuando ésta se dirige a honrar la humanidad y a perfeccionarle su suerte' [If there is any just violence it is that which is employed in making men good and, in consequence, free; and there is no legitimate freedom except when it aims to honour humanity and improve its lot]. ${ }^{62}$ This was one of the greatest challenges to be met in Spanish America; Bolívar set out to confront it in his first constitutional project, the Venezuelan Constitution of 1819 , which will be the basis for the Constitution of 'Great' Colombia two years later.

In the period 1816-1819, therefore, a new conception of the social contract began to take shape in Bolívar's thought. If the arguments presented in the Jamaica Letter applied principles of natural law in order to legitimize the political hegemony of the creole class over the vast majority of the native population, by 1819 Bolívar was able to formulate a republican constitutional order based on the legal equality of all members of society which included the abolition of slavery and, a few years later, the legal protection of basic indigenous rights. ${ }^{63}$ This meant a crucial turn from the notion of 
natural rights as the basis of the social pact to an idea of society which relied, more than ever before in Bolívar's political doctrine, on the application of civil rights as a means to protect the liberty and equality of its citizens. ${ }^{64}$ This is stated clearly in the Angostura Address:

La naturaleza hace a los hombres desiguales, en genio, temperamento, fuerzas y caracteres. Las leyes corrigen esta diferencia porque colocan al individuo en la sociedad para que la educación, la industria, las artes, los servicios, las virtudes le den una igualdad ficticia, propiamente llamada política y social.

[Nature makes men unequal, in intelligence, temperament, strength, and character. The laws correct this difference because they place the individual in society so that education, industry, the arts, the services and the virtues can give him a fictitious equality that is properly called political and social. $]^{65}$

Despite a number of measures proposed by the Liberator to curtail popular participation in the future political process (such as the distinction between 'active' and 'passive' citizenship), the implications of his social doctrine proved to be too revolutionary for his time. In a deeply hierarchical and racially stratified society economically dependent on slave work force, the ideas of universal freedom and equality were doomed to meet strong opposition. Not surprisingly, the Venezuelan Congress watered down Bolívar's plea for the abolition of slavery. ${ }^{66}$ It is for his biographers to determine whether or not his intentions in proclaiming the liberty of all men were sincere. In this article, I have argued that the Liberator's actions obeyed a fundamental conviction about the nature of republican government and the means through which it could be adopted in Spanish America. In an attempt to overcome the political limitations that colonial experience had imposed on its inhabitants, and placing his faith in the capacity of the human race for moral and intellectual development, 
Bolívar's constitutional project of 1819 opened up the way to radical social and political reform, a path that was frustrated by the very prejudices it tried to confront.

\section{Notes}

1. Brading, "Bourbon Spain,” 112-162; Lynch, Bourbon Spain, 329-374; McFarlane, Colombia Before Independence, 99-184; Rodríguez Ordóñez, La independencia, 52-80. 2. Verna, Petión y Bolívar, 145-157; Lynch, The Spanish American Revolutions, 19-24, 28-29; Domínguez, Insurrection or Loyalty, 28-45; Andrien, Andean Worlds, 202-232; Helg, Liberty and Equality, 42-79; Andrews, Afro-Latin America, 11-52; Lasso, Myths of Harmony, 16-33.

3. Bolívar to Alexandre Dehollain, 23 June 1806, in Bolívar, Obras completas, 1: 26 (my translation). See Ramos Pérez, "A los dos siglos," 37-40.

4. 'Que los buenos e inocentes indios, así como los bizarros pardos, y morenos libres crean firmemente, que somos todos conciudadanos, y que los premios pertenecen exclusivamente al mérito y a la Virtud en cuya suposición obtendrán en adelante infaliblemente, las recompensas militares y civiles, por su mérito solamente', Proclama a los Pueblos del Continente Américo-Colombiano, in Miranda, América espera, 356 (my italics). See Robertson, The life of Miranda, 1: 47, 50, 57; 2: 237-238; Bohórquez Morán, Francisco de Miranda, 218-221, 334-337; Lynch, "Francisco de Miranda," 22-53.

5. Miranda's own father was a victim of racial and social discrimination, see Hernández González, "Lo canario,” 37-51. More generally, McKinley, Pre-revolutionary Caracas, 9-28.

6. On the failure of Miranda's expedition and its context, see Biggs, The History of Don Francisco, 255-257; Robertson, The Life of Miranda, 1: 236-243, 255-265, 293-327;

Kaufmann, British Policy, 9-17, 19-23; Deas, "Some Reflections," 77-87.

7. Chust and Frasquet, Las independencias en América, 17-38.

8. Ramos Pérez, Emancipación y nacionalidades americanas, 101-102.

9. See Rieu-Millán, Los diputados americanos, 265-411.

10. Rodríguez Ordóñez, La independencia, 202. For a global perspective, see Blaufarb, “The Western Question," 742-763.

11. Gil Fortoul, Historia Constitucional de Venezuela, 1: 163-275; Parra-Pérez, Historia de la Primera República, 195-545. 
12. Robertson, The Life of Miranda, 1: 81-86; Gil Fortoul, Historia Constitucional, 1: 182-186; Parra-Pérez, Historia de la Primera República, 242-254; Waddell, Gran Bretaña y la Independencia, 60-72; Lynch, Simón Bolívar: A Life, 49-54.

13. Lynch, "Great Britain," 39-42; Lambert, "Los legionarios británicos,” 355-376; McFarlane, "British Foreign Policy," 16, 19-20.

14. Robertson, The Life of Miranda, 1: 120-141.

15. 'We have before our eyes two great examples, the American and the French Revolutions. Let us prudently imitate the first and carefully shun the second', Miranda to Gual, 31 December 1799; cited in Lynch, Simón Bolívar: A Life, 30. See Racine, Francisco de Miranda, 219-220; Bohórquez Morán, Francisco de Miranda, 222-236. 16. Robertson, The Life of Miranda, 2: 167-195; Parra-Pérez, Historia de la Primera República, 553; McFarlane, War and Independence, 93-95.

17. Bolívar, Doctrina del Libertador, 9. For a critical assessment of Bolívar's political creed, see Guerrero, "Del mar de las Antillas," 199-221.

18. Bolívar, Doctrina del Libertador, 9; Bolívar, El Libertador, 4, respectively. See Gil Fortoul, Historia Constitucional, 1: 293-297; Parra-Pérez, Historia de la Primera República, 564-573; Belaúnde, Bolívar, 181-196.

19. Gil Fortoul, Historia Constitucional, 1: 219-221; Parra-Pérez, Historia de la Primera República, 367; Belaúnde, Bolívar, 163; Kinsbruner, Independence in Spanish America, $124-125$.

20. Bolívar to Luis López Méndez, 21 November 1817, in Urdaneta, 388. See Ocampo López, El proceso ideológico, 314-318.

21. Bolívar, Doctrina del Libertador, 12; Bolívar, El Libertador, 6. In his address to the Angostura Congress of 1819, Bolívar will define the republican ethos as 'el amor a la patria, el amor a las leyes, el amor a los magistrados', Doctrina del Libertador, 121. For the notion of political virtue in Bolívar's thought, see Guerrero, Republicanismo y liberalismo, 27-106.

22. Urueña Cervera, Bolívar republicano, 76, 188-189; Chiaramonte, Fundamentos intelectuales, 87-89, 110-116.

23. König, En el camino hacia la nación, 274-313; Quijada, “¿Qué Nación?,” 19-31;

Guerra, Modernidad e independencias, 390-466; Chiaramonte, Nación y Estado, 27-57;

Cardozo Galué, "Regiones históricas," 1-35.

24. Manifiesto de Cartagena, in Bolívar, Doctrina del Libertador, 13; Bolívar, El

Libertador, 7. See Lynch, Simón Bolívar: A Life, 65-68. 
25. Proclama a los Venezolanos, convocando el Congreso de Venezuela, Angostura, 22 October 1818, in Bolívar, Obras completas, 2: 1128 (my translation). See Guerrero, Republicanismo y liberalismo, 145-146; Adelman, Sovereignty and Revolution, 345, 365-367; Urueña Cervera, Bolívar republicano, 248.

26. See Reyes Cárdenas, "El derrumbe," 39-61. For the colonial background, see McFarlane, "Political Corruption," 41-63.

27. Gil Fortoul, Historia Constitucional, 1: 337-339, 426; Waddell, Gran Bretaña y la Independencia, 173-182, 198-199; Lynch, Simón Bolívar: A Life, 68-90; McFarlane, War and Independence, 111-140.

28. Bolívar to Richard Wellesley, 27 May 1815; in Bolívar, El Libertador, 154; see also Bolívar, Obras completas, 1: 137.

29. Earle, Spain and the Independence, 60-65; Thibaud, République en armes, 203-205; McFarlane, War and Independence, 138-139.

30. The English version of the Jamaica Letter (which has erroneously been dated 1818 by several scholars) was first published in The Jamaica Quarterly Journal and Literary Gazette in September 1819. See “General Bolivar's (sic) Letter to a Friend," 162-74. All further English quotations are taken from this edition, a copy of which is available at the British Library. For the fortunes of the text, see Bolívar, Carta de Jamaica, 3-25 (note, however, that this critical edition of the Letter seems to have originated the chronological confusion mentioned above). For the original Spanish manuscript, see Zambrano, "Un hallazgo bicentenario," 38-41.

31. 'Al mismo tiempo se puede entregar al gobierno británico las provincias de Panamá y Nicaragua, para que forme de estos países el centro del comercio del universo por medio de la apertura de canales, que, rompiendo los diques de uno y otro mar, acerque las distancias más remotas y hagan permanente el imperio de la Inglaterra sobre el comercio', Bolívar to Maxwell Hyslop, 19 May 1815, in Bolívar, Obras completas, 1: 134. On Miranda's distrust, see Robertson, The Life of Miranda, 1: 240-243; Berruezo León, La lucha de Hispanoamérica, 51.

32. For a contextualization, see Pino Iturrieta, Nueva lectura, 1-57; Lynch, Simón Bolivar: A Life, 91-97; Helg, "Simón Bolívar's Republic," 22-23.

33. Bolívar, Doctrina del Libertador, 67-68; Bolívar, "General Bolivar's Letter," 169.

34. For a discussion of the main issues, see Brading, The First America, 422-464.

35. The theme runs through Bolívar's entire political career. See, for instance, Bolívar to White, 26 May 1820: 'Tenga Vd. la bondad de leer con atención mi discurso [ante el Congreso de Angostura], sin atender a sus partes, sino al todo de él. Su conjunto prueba 
que yo tengo muy poca confianza en la moral de nuestros ciudadanos y que sin moral republicana no puede haber gobierno libre', in Bolívar, Doctrina del Libertador, 150; Bolívar to Santander, 13 September 1822: '[Heres] asegura que la actividad de los godos es infinita, y la corrupción de los nuestros también infinita; que la indisciplina, la falta de entusiasmo, falta de sistema y, en una palabra, falta de cabeza de los independientes, contrasta con las cualidades que tienen los realistas', in Bolívar, Obras Completas, 1: 680.

36. Bolívar, Doctrina del Libertador, 74; Bolívar, "General Bolivar's Letter," 174 (I have added the final clause of the sentence, which is missing in the English translation). $C f$. Guerrero, "Del mar de las Antillas," 208-209.

37. Thomas Jefferson to John Adams, 22 January 1821, cited in Vajda, "Thomas Jefferson," 282. Cf. Hegel, Lectures, 166: 'North America owes its prosperity to the growth of its industry and population and to civil order and firmly established freedom. [...] In South America, however, the republics are based solely on military force; their whole history is one of continuous revolution.'

38. Gil Fortoul, Historia Constitucional, 1: 431-432, 434; Rozo Acuña, "Estudio preliminar," in Bolívar, Obra política y constitucional, CXLIII-CL; Crespo, Del rey al presidente, 240-256. But see Guerrero, "Mesianismo," 153-154; Guerrero, Republicanismo y liberalismo, 308-364.

39. 'La creación de un cuerpo político y aun se podría decir la creación de una sociedad entera', Bolívar, Doctrina del Libertador, 104.

40. Bolívar to White, 5 October 1818, in Escritos del Libertador, 14: 356 (original in English).

41. 'Yo quiero ser ciudadano, para ser libre y para que todos lo sean. Prefiero el título de ciudadano al de Libertador, porque éste emana de la guerra, aquél emana de las leyes', Discurso ante el Congreso de Cúcuta (1821), in Bolívar, Doctrina del Libertador, 161. 42. Ramos Pérez, Bolívar, 154-155; Röhrig Assunção, "L’adhésion populaire," 291-313; Hamnett, "Popular Insurrection," 43-71; Andrews, Afro-Latin America, 58-62; Brown, Adventuring Through Spanish Colonies, 133-155; Chaves, "Esclavos, libertades y república," 81-104.

43. See Lynch, Simón Bolívar and the Age, 5-6, 12, 18-19; Lynch, Simón Bolivvar: A Life, 108-109, 146-155; Arcos Rivas, "La multitud de libres," 1-14; Helg, "Simón Bolívar's Republic," 23-24; Fischer, "Bolívar in Haiti," 25-53. For a wider appraisal, see Blanchard, "The Language of Liberation," 499-523; Andrews, Afro-Latin America, 1152; Lasso, Myths of Harmony, 57-90. 
44. Lombardi, "Los esclavos negros," 165; Davis, The Problem of Slavery, 81; Röhrig Assunção, "L’adhésion populaire,” 298-299; Hamnett, "Popular Insurrection," 55; Blanchard and Ryder, "Los soldados-esclavos," 27-28; McFarlane, War and Independence, 78.

45. Lombardi, "Los esclavos negros," 154-157; Earle, Spain, 58; Thibaud, République en armes, 226-228; Blanchard, Under the Flags, 17-36.

46. Discurso a los habitantes de la Costa Firme, 23 May 1816, in Bolívar, Obras completas, 2: 1092 (my translation). See Lombardi, "Los esclavos negros," 160-161; Brito Figueroa, "Venezuela colonial," 263-289; Lynch, Simón Bolivar and the Age, 18; Múnera, El fracaso de la nación, 173-215; Blanchard, Under the Flags, 65-67; McFarlane, War and Independence, 318-319.

47. Bolívar to Santander, 10 May 1820, in Bolívar, Obras completas, 1: 435 (my translation). See Bierck, “The Struggle for Abolition,” 368-369; Rout, The African Experience, 236-237.

48. Bolívar to Santander, 20 April 1820, in Bolívar, Obras completas, 1: 425; Bolívar, El Libertador, 183 (my italics).

49. Brito Figueroa, Las insurrecciones, 82-93; Rout, The African Experience, 109-116; McFarlane, "Cimarrones and palenques," 141-143; Rojas, "Rebeliones de esclavos negros," 151-164; Helg, “A Fragmented Majority,” 164-166; Blanchard, Under the Flags, 116; Thompson, Huida a la libertad, 297-301.

50. See Earle, The Return, 40-43.

51. Ensayo dirigido al editor de la Gaceta Real de Jamaica, in Bolívar, Doctrina del Libertador, 75-79. See Lombardi, "Los esclavos negros,” 159; Ramos Pérez, Bolívar, 17-24; Pino Iturrieta, Nueva lectura, 24, 33-39; Lynch, Simón Bolívar: A Life, 95; Helg, “Simón Bolívar's Republic,” 22-23.

52. Bolívar, "General Bolivar's Letter," 167 (italics in the original); see also Bolívar, Doctrina del Libertador, 64. The Spanish version of the Jamaica Letter does not include the sentence "that they should take the "indigenes" under their protection as vassals'; on this issue, see Portillo Valdés, Crisis atlántica, 185. On the alleged pact between the Spanish monarch and the Conquistadors, see de Mier, Ideario político, 77-164; Brading, The First America, 593-594; Guerrero, "Del mar de las Antillas," 202-207.

53. Rodríguez Ordóñez, "La independencia," 571-620; Helg, "The Limits of Equality," 20; Rueda Santos, "La participación popular," 41-64; Blanchard and Ryder, "Los soldados-esclavos," 30-31. 
54. Consider, for instance, Pedro Fermín de Vargas's discriminatory remarks back in 1790: 'La indolencia general de ellos, su estupidez y la insensibilidad que manifiestan hacia todo aquello que mueve y alienta a los demás hombres, hace pensar que vienen de una raza degenerada que se empeora en razón de la distancia de su origen', Pensamientos Políticos, 99. See Earle, “Creole Patriotism,” 125-145; Múnera, Fronteras imaginadas, 45-88, 129-152; Castillo Gómez, Etnicidad y nación, 61-70.

55. Indian support of Royalist forces in some parts of New Granada, for instance, was linked to territorial disputes with elite landowners; by taking sides with the Spaniards, the Indians sought protection from the Crown. See Sæther, Identidades e independencia, 196-197; Gutiérrez Ramos, Los indios de Pasto, 153-207; Helg, “Simón Bolívar's Republic,"31-34; Echeverri, Indian and Slave Royalists, 123-155.

56. Bolívar, Doctrina del Libertador, 62; Bolívar, "General Bolivar's Letter," 166 (my italics). The expression 'los legítimos propietarios del país' [legitimate owners of the land] is not found in the English version of the text. Bolívar inserted this passage with some modifications in his address to the Angostura Congress; see Bolívar, Doctrina del Libertador, 104; Bolívar, El Libertador, 33.

57. Urueña Cervera, Bolívar republicano, 56-60.

58. 'La sangre de nuestros ciudadanos es diferente, mezclémosla para unirla', Bolívar, Doctrina del Libertador, 121. See Collier, "Nationality, Nationalism, and Supranationalism," 43; Pino Iturrieta, Nueva lectura, 26; von Vacano, The Color of Citizenship, 60.

59. ¿¿Quiénes son los autores de esta Revolución? ¿No son los blancos, los ricos, los títulos de Castilla y aun los jefes militares al servicio del rey?', Manifiesto de Bolívar a los pueblos de Venezuela, 5 August 1817, in Bolívar, Obras completas, 2: 1105 (this manifesto was published on the occasion of General Manuel Piar's mulatto insurrection in 1817 against the dominant caraqueño elite). See Ramos Pérez, Bolívar, 150-164; Múnera, El fracaso de la nación, 29-75; Guerra, "De lo uno a lo múltiple,” 43-68; Lynch, Simón Bolivar: A Life, 102-107; Thibaud, République en armes, 246-247; Helg, "Simón Bolívar’s Republic," 26-31.

60. Bolívar, Doctrina del Libertador, 72; Bolívar, "General Bolivar's Letter," 172. See Belaúnde, Bolívar, 175-179; Collier, "Nationality, Nationalism, and Supranationalism," 48-55; Castro-Klarén, "Framing Pan-Americanism,” 25-53; Tejada Ripalda, “El americanismo," 169-176.

61. But see Castro Leiva and Pagden, "Civil Society," 183-191. 
62. Bolívar to White, 26 May 1820, in Bolívar, Doctrina del Libertador, 151 (my translation). $C f$. ibid., 123; Bolívar, El Libertador, 50.

63. 'No se puede ser libre y esclavo a la vez, sino violando [...] las leyes naturales, las leyes políticas, y las leyes civiles. [...] Yo imploro la confirmación de la Libertad absoluta de los esclavos, como imploraría mi vida y la vida de la República', Bolívar, Doctrina del Libertador, 124. On Indian rights, see Decreto sobre los derechos del indio (1820), in Bolívar, Decretos del Libertador, 1: 194-197. See also Bolívar, El Libertador, 184-86. Cf. Gil Fortoul, Historia Constitucional, 1: 434-436; Bierck, "The Struggle for Abolition," 367-372.

64. 'Bolívar impulsó la completa emancipación de los indios. En 1813-1814, respetó los acuerdos de extinción de la servidumbre. Y, luego, a partir de 1817, se interesó por la plena igualdad civil de los indios', Paira Reinoso, "El pretendido establecimiento," 172. See also Rudan, "Más allá," 134-135; Rojas, "La esclavitud liberal," 35-37. But see Guerrero, "Del mar de las Antillas," 201, 209-211.

65. Bolívar, Doctrina del Libertador, 111; Bolívar, El Libertador, 39.

66. Rojas, "Rebeliones de esclavos negros," 163-164; Davis, The Problem of Slavery, 91.

\section{Bibliography}

Adelman, Jeremy. Sovereignty and Revolution in the Iberian Atlantic. Princeton, NJ: Princeton University Press, 2006.

Andrews, George Reid. Afro-Latin America, 1800-2000. Oxford: Oxford University Press, 2004.

Andrien, Kenneth J. Andean Worlds: Indigenous History, Culture, and Consciousness Under Spanish Rule, 1532-1825. Albuquerque: University of New Mexico Press, 2001.

Arcos Rivas, Arleison. "La multitud de libres y de todos los colores." Diálogos de Derecho y Política, 6 (2011): 1-14.

Belaúnde, Víctor Andrés. Bolívar y el pensamiento político de la revolución hispanoamericana. Madrid: Ediciones Cultura Hispánica, 1959.

Berruezo León, María Teresa. La lucha de Hispanoamérica por su independencia en Inglaterra. 1800-1830. Madrid: Ediciones de Cultura Hispánica, 1989.

Bierck, Harold A. "The Struggle for Abolition in Gran Colombia." The Hispanic American Historical Review 33, no. 3 (1953): 365-386.

Biggs, James. The History of Don Francisco de Miranda's Attempt to Effect a Revolution in South America, in a Series of Letters. Boston: Oliver and Munroe, 1808.

Blanchard, Peter. "The Language of Liberation: Slave Voices in the Wars of Independence." Hispanic American Historical Review, 82 (2002): 499-523.

Blanchard, Peter. Under the Flags of Freedom: Slave Soldiers and the Wars of Independence in Spanish South America. Pittsburgh: University of Pittsburgh Press, 2008.

Blanchard, Peter and Cecilia Ryder. "Los soldados-esclavos y las Guerras de Independencia en Hispanoamérica." Guaraguao. Revista de Cultura Latinoamericana, 39 (2012): 25-48. 
Blaufarb, Rafe. "The Western Question: The Geopolitics of Latin American Independence." American Historical Review 112, no. 3 (2007): 742-763.

Bohórquez Morán, Carmen L. Francisco de Miranda. Precursor de las Independencias de la América Latina. 3rd ed. Caracas: El Perro y la Rana Ediciones, 2006.

Bolívar, Simón. Carta de Jamaica. Edited by Cristóbal L. Mendoza. Caracas: Ediciones de la Presidencia de la República, 1972.

Bolívar, Simón. Decretos del Libertador. 3 vols. Edited by Vicente Lecuna. Caracas: Imprenta Nacional, 1961.

Bolívar, Simón. Doctrina del Libertador. Edited by Manuel Pérez Vila. Caracas: Biblioteca Ayacucho, 1985.

Bolívar, Simón. Escritos del Libertador. Caracas: Sociedad Bolivariana de Venezuela, 1967[1981].

Bolívar, Simón. "General Bolivar's (sic) Letter to a Friend, on the Subject of South-American Independence." The Jamaica Quarterly Journal and Literary Gazette 3, no. 1 (1819): 162 174.

Bolívar, Simón. El Libertador: Writings of Simón Bolívar. Edited by David Bushnell, translated by Frederick H. Fornoff. Oxford: Oxford University Press, 2003.

Bolívar, Simón. Obras completas. 2 vols. Edited by Vicente Lecuna and Esther Barret de Nagaris. La Habana: Editorial Lex, 1947.

Bolívar, Simón. Obra política y constitucional. Edited by Eduardo Rozo Acuña. Madrid: Editorial Tecnos, 2007.

Brading, David A. "Bourbon Spain and Its American Empire." In Colonial Spanish America, edited by Leslie Bethell, 112-162. Cambridge: Cambridge University Press, 1987.

Brading, David A. The First America: The Spanish Monarchy, Creole Patriots and the Liberal State 1492-1866. Cambridge: Cambridge University Press, 1991.

Brito Figueroa, Federico. Las insurrecciones de los esclavos negros en la sociedad colonial venezolana. Caracas: Editorial Cantaclaro, 1961.

Brito Figueroa, Federico. "Venezuela colonial: las rebeliones de esclavos y la Revolución francesa." Caravelle, 54 (1990): 263-289.

Brown, Matthew. Adventuring Through Spanish Colonies: Simón Bolivar, Foreign Mercenaries and the Birth of New Nations. Liverpool: University of Liverpool Press, 2006.

Cardozo Galué, Germán. "Regiones históricas, independencia y construcción de la nación venezolana." Académica 2, no. 3 (2010): 1-35.

Castillo Gómez, Luis Carlos. Etnicidad y nación. El desafío de la diversidad en Colombia. Cali: Universidad del Valle, 2007.

Castro-Klarén, Sara. "Framing Pan-Americanism: Simón Bolívar's Findings.” The New Centennial Review 3, no. 1 (2003): 25-53.

Castro Leiva, Luis and Anthony Pagden. "Civil Society and the Fate of the Modern Republics of Latin America." In Civil Society: History and Possibilities, edited by Sudipta Kaviraj and Sunil Khilnani, 179-203. Cambridge: Cambridge University Press, 2001.

Chaves, María Eugenia. "Esclavos, libertades y república. Tesis sobre la polisemia de la libertad en la primera república antioqueña." Estudios Interdisciplinarios de América Latina y el Caribe 22, no. 1 (2011): 81-104.

Chiaramonte, José Carlos. Fundamentos intelectuales y políticos de las independencias. Buenos Aires: Editorial Teseo, 2010.

Chiaramonte, José Carlos. Nación y Estado en Iberoamérica: el lenguaje político en tiempos de las independencias. Buenos Aires: Editorial Sudamericana, 2004.

Chust, Manuel and Ivana Frasquet. Las independencias en América. Madrid: Los Libros de la Catarata, 2009.

Collier, Simon. "Nationality, Nationalism, and Supranationalism in the Writings of Simón Bolívar." The Hispanic American Historical Review 63, no. 1 (1983): 37-64.

Crespo, María Victoria. Del rey al presidente: poder Ejecutivo, formación del Estado y soberanía en la Hispanoamérica revolucionaria, 1810-1826. México: El Colegio de México, 2013. 
Davis, David Brion. The Problem of Slavery in the Age of Revolution, 1770-1823. Oxford: Oxford University Press, 1999.

de Mier, Servando Teresa. Ideario político. Edited by Edmundo O'Gorman. Caracas: Biblioteca Ayacucho, 1978.

de Miranda, Francisco. América espera. Edited by J. L. Salcedo-Bastardo. Caracas: Biblioteca Ayacucho, 1982.

de Vargas, Pedro Fermín. Pensamientos Políticos y Memoria sobre la población del Nuevo Reino de Granada. Bogotá: Imprenta Nacional, 1944.

Deas, Malcolm. "Some Reflections on Miranda as Soldier." In Francisco de Miranda: Exile and Enlightenment, edited by John Maher, 77-87. London: Institute for the Study of the Americas, 2006.

Domínguez, Jorge I. Insurrection or Loyalty. The Breakdown of the Spanish American Empire. Cambridge, MA: Harvard University Press, 1980.

Earle, Rebecca A. "Creole Patriotism and the Myth of the 'Loyal Indian'." Past and Present, 172 (2001): 125-145.

Earle, Rebecca A. Spain and the Independence of Colombia 1810-1825. Exeter: University of Exeter Press, 2000.

Earle, Rebecca A. The Return of the Native: Indians and Myth-Making in Spanish America, 1810-1930. Durham: Duke University Press, 2007.

Echeverri, Marcela. Indian and Slave Royalists in the Age of Revolution: Reform, Revolution, and Royalism in the Northern Andes, 1780-1825. New York, NY: Cambridge University Press, 2016.

Fischer, Sibylle. "Bolívar in Haiti: Republicanism in the Revolutionary Atlantic." In Haiti and the Americas, edited by Carla Calargé, Raphael Dalleo, Luis Duno-Gottberg and Clevis Headley, 25-53. Jackson: University Press of Mississippi, 2013.

Gil Fortoul, José. Historia Constitucional de Venezuela. 2nd edn, 3 vols. Caracas: Parra León Hermanos, 1930.

Guerra, François-Xavier. "De lo uno a lo múltiple: Dimensiones y lógicas de la Independencia." In Independence and Revolution in Spanish America: Perspectives and Problems, edited by Anthony McFarlane and Eduardo Posada-Carbó, 43-68. London: Institute of Latin American Studies, 1999.

Guerra, François-Xavier. Modernidad e independencias. Ensayos sobre las revoluciones hispánicas. Madrid: Ediciones Encuentro, 2009.

Guerrero, Carolina. "Del mar de las Antillas a los Andes: el pacto en la retórica republicana de Bolívar." In La República peregrina: hombres de armas y letras en América del Sur. 1800 1884, edited by Carmen Mc Evoy and Ana María Stuven, 199-221. Lima: Instituto Francés de Estudios Andinos; Instituto de Estudios Peruanos, 2007.

Guerrero, Carolina. "Mesianismo en la idea de dictadura en América Hispánica." Politeia, 28 (2002): 141-158.

Guerrero, Carolina. Republicanismo y liberalismo en Bolivar (1819-1830): usos de Constant por el padre fundador. Caracas: Universidad Central de Venezuela, 2005.

Gutiérrez Ramos, Jairo. Los indios de Pasto contra la República (1809-1824). Bogotá: Instituto Colombiano de Antropología e Historia, 2007.

Hamnett, Brian R. "Popular Insurrection and Royalist Reaction: Colombian Regions, 18101823." In The Wars of Independence in Spanish America, edited by Christon I. Archer, 4371. Wilmington, DE: Scholarly Resources, 2000.

Hegel, G. W. F. Lectures on the Philosophy of World History. Translated by H. B. Nisbet. Cambridge: Cambridge University Press, 1975.

Helg, Aline. "A Fragmented Majority Free "Of All Colors": Indians and Slaves in Caribbean Colombia During the Haitian Revolution." In The Impact of the Haitian Revolution in the Atlantic World, edited by David P. Geggus, 157-175. Columbia: The University of South Carolina Press, 2001.

Helg, Aline. Liberty and Equality in Caribbean Colombia, 1770-1835. Chapel Hill: The University of North Carolina Press, 2004. 
Helg, Aline. "The Limits of Equality: Free People of Colour and Slaves During the First Independence of Cartagena, Colombia, 1810-15.” Slavery \& Abolition 20, no. 2 (1999): 130.

Helg, Aline. "Simón Bolívar's Republic: A Bulwark Against the "Tyranny" of the Majority." Revista de Sociologia e Política 20, no. 42 (2012): 21-37.

Hernández González, Manuel. "Lo canario en Francisco de Miranda." Catharum, 7 (2006): 37 51.

Kaufmann, William W. British Policy and the Independence of Latin America. London: Frank Cass, 1967.

Kinsbruner, Jay. Independence in Spanish America: Civil Wars, Revolutions and Underdevelopment. 2nd ed. Albuquerque: University of New Mexico Press, 2000.

Kőnig, Hans-Joachim. En el camino hacia la nación: nacionalismo en el proceso de formación del estado y de la nación de la Nueva Granada, 1750-1856. Santafé de Bogotá: Banco de la República, 1994.

Lambert, Eric. "Los legionarios británicos." In Bello y Londres: Segundo Congreso del Bicentenario. 2 vols. Edited by Oscar Sambrano Urdaneta. Caracas: Fundación La Casa de Bello, 1980-81. Vol. 1: 355-376.

Lasso, Marixa. Myths of Harmony: Race and Republicanism During the Age of Revolution, Colombia 1795-1831. Pittsburgh, PA: University of Pittsburgh Press, 2007.

Lombardi, John V. "Los esclavos negros en las guerras venezolanas de la independencia." Cultura Universitaria, 93 (1966): 153-168.

Lynch, John. "Francisco de Miranda: The London Years." In Francisco de Miranda: Exile and Enlightenment, edited by John Maher, 22-53. London: Institute for the Study of the Americas, 2006.

Lynch, John. "Great Britain and Latin American Independence, 1810-1830.” In Bello y Londres: Segundo Congreso del Bicentenario. 2 vols. Edited by Oscar Sambrano Urdaneta. Caracas: Fundación La Casa de Bello, 1980-81. Vol. 1: 33-51.

Lynch, John. Simón Bolívar: A Life. New Haven: Yale University Press, 2006.

Lynch, John. Simón Bolivar and the Age of Revolution. Working Papers n. 10. London: University of London, Institute of Latin American Studies, 1983.

Lynch, John. "Spain and America." Chap. 9 in Bourbon Spain, 1700-1808. Oxford: Basil Blackwell, 1989.

Lynch, John. The Spanish American Revolutions, 1808-1826. New York: W. W. Norton, 1973.

McFarlane, Anthony. "British Foreign Policy and the Independence of Colombia, 1810-1825." In The Role of Great Britain in the Independence of Colombia, edited by Olga Lucía Sorzano Montaña, 10-21. Bogotá: Ministry of Foreign Affairs, 2011.

McFarlane, Anthony. "Cimarrones and palenques: Runaways and Resistance in Colonial Colombia." Slavery \& Abolition 6, no. 3 (1985): 131-151.

McFarlane, Anthony. Colombia Before Independence: Economy, Society, and Politics Under Bourbon Rule. Cambridge: Cambridge University Press, 1993.

McFarlane, Anthony. "Political Corruption and Reform in Bourbon Spanish America." In Political Corruption in Europe and Latin America, edited by Walter Little and Eduardo Posada-Carbó, 41-63. Basingstoke: Macmillan, 1996.

McFarlane, Anthony. War and Independence in Spanish America. New York: Routledge, 2014.

McKinley, P. Michael. Pre-revolutionary Caracas: Politics, Economy and Society 1777-1811. Cambridge: Cambridge University Press, 1985.

Múnera, Alfonso. El fracaso de la nación. Región, clase y raza en el Caribe colombiano (17171821). Bogotá: Banco de la República, El Áncora Editores, 1998.

Múnera, Alfonso. Fronteras imaginadas. La construcción de las razas y de la geografía en el Siglo XIX colombiano. Bogotá: Editorial Planeta, 2005.

Ocampo López, Javier. El proceso ideológico de la emancipación. Medellín: La Carreta Editores, Universidad Pedagógica y Tecnológica de Colombia, 2010.

Paira Reinoso, Antonio. "El pretendido establecimiento de los tributos personales de los indios por parte del Libertador en 1828." Cultura Universitaria, 93 (1966): 169-175. 
Parra-Pérez, Caracciolo. Historia de la Primera República de Venezuela. Caracas: Biblioteca Ayacucho, 1992.

Pino Iturrieta. Nueva lectura de la Carta de Jamaica. Caracas: Monte Ávila Editores, 1999.

Portillo Valdés, José M. Crisis atlántica. Autonomía e independencia en la crisis de la monarquía hispana. Madrid: Marcial Pons, 2006.

Quijada, Mónica. “¿Qué Nación? Dinámicas y dicotomías de la nación en el imaginario hispanoamericano del siglo XIX.” In Imaginar la Nación, edited by François-Xavier Guerra and Mónica Quijada, 19-31. Münster: AHILA, Cuadernos de Historia, 1994.

Racine, Karen. Francisco de Miranda: A Transatlantic Life in the Age of Revolution. Wilmington, DE: Scholarly Resources, 2003.

Ramos Pérez, Demetrio. "A los dos siglos del viaje a España de Simón Bolívar: la causa y su deseo de instalarse en la corte para algo muy distinto que 'dedicarse a la carrera de armas'." Boletín de la Real Academia de la Historia 196, no. 1 (1999): 37-40.

Ramos Pérez, Demetrio. Bolívar y su experiencia antillana: una etapa decisiva para su línea política. Caracas: Academia Nacional de la Historia, 1990.

Ramos Pérez, Demetrio. Emancipación y nacionalidades americanas. Vol. 13 of Historia General de España y América. Edited by Luis Suárez Fernández. Madrid: Ediciones Rialp, 1992.

Reyes Cárdenas, Ana Catalina. "El derrumbe de la primera república en la Nueva Granada entre 1810-1816." Historia Crítica, 41 (2010): 39-61.

Rieu-Millán, Marie-Laure. Los diputados americanos en las Cortes de Cádiz: igualdado independencia. Madrid: Consejo Superior de Investigaciones Científicas, 1990.

Robertson, William Spence. The life of Miranda. 2 vols. Chapel Hill: The University of North Carolina Press, 1929.

Rodríguez Ordóñez, Jaime E. La independencia de la América española. 2nd ed. Mexico: Fondo de Cultura Económica, 2008.

Rodríguez Ordóñez, Jaime E. "La independencia de la América española: una reinterpretación." Historia Mexicana 42, no. 3 (1993): 571-620.

Röhrig Assunção, Matthias. "L'adhésion populaire aux projets révolutionnaires dans les sociétés esclavagistes: le cas du Venezuela et du Brésil (1780-1840)." Caravelle, 54 (1990): 291-313.

Rojas, Rafael. "La esclavitud liberal. Liberalismo y abolicionismo en el Caribe hispano." Secuencia, 86 (2013): 29-52.

Rojas, Reinaldo. "Rebeliones de esclavos negros en Venezuela antes y después de 1789." Estudios de Historia Social y Económica de América, 10 (1993): 151-164.

Rout, Leslie B. The African Experience in Spanish America, 1502 to the Present Day. Cambridge: Cambridge University Press, 1976.

Rudan, Paola. "Más allá de la querella benthamista: el gobierno de Ultramaria." Araucaria, 23 (2010): 115-139.

Rueda Santos, Rigoberto. "La participación popular en la independencia de Nueva Granada según la historiografía reciente. Un balance." Procesos, 29 (2009): 41-64.

Sæther, Steinar A. Identidades e independencia en Santa Marta y Riohacha, 1750-1850. Bogotá: Instituto Colombiano de Antropología e Historia, 2012.

Tejada Ripalda, Luis. "El americanismo. Consideraciones sobre el nacionalismo continental latinoamericano." Investigaciones Sociales 8, no. 12 (2004): 167-200.

Thibaud, Clément. République en armes. Les armées de Bolívar dans les guerres d'indépendence du Venezuela et de la Colombie. Rennes: Pressses Universitaires de Rennes, 2006.

Thompson, Alvin O. Huida a la libertad: fugitivos y cimarrones africanos en el Caribe. Mexico: Siglo Veintiuno Editores, 2005.

Urdaneta, Alberto, ed. Papel Periódico Ilustrado. Bogotá: Imprenta de Silvestre, 1881-88. 47: 387-390.

Urueña Cervera, Jaime. Bolívar republicano. Fundamentos ideológicos e históricos de su pensamiento político. Bogotá: Ediciones Aurora, 2007. 
Vajda, Zoltán. "Thomas Jefferson on the Character of an Unfree People: The Case of Spanish America." American Nineteenth Century History 8, no. 3 (2007): 273-292.

Verna, Paul. Petión y Bolívar. Caracas: Ministerio de Educación, 1969.

von Vacano, Diego A.. The Color of Citizenship: Race, Modernity and Latin American/Hispanic Political Thought. Oxford: Oxford University Press, 2012.

Waddell, David A. G. Gran Bretaña y la Independencia de Venezuela y Colombia. Caracas: [Ministerio de Educación] 1983.

Zambrano, Alexander. "Un hallazgo bicentenario. Manuscrito en castellano de la Carta de Jamaica." Memorias, 33 (2015): 38-41. 